\title{
QUARTERLY EARNNGS ANNOUNCEMENT AND ITS IMPACT ON STOCK RETURNS
}

\begin{tabular}{|l|l|}
\hline HEMARAJA M SHETTY & Dr. KUSHALAPPA. S \\
Research Scholar, & Senior Assistant Professor, \\
AIET, Mijar, Moodbidri-574 225 & AIET, Mijar, Moodbidri -574 225 \\
\hline
\end{tabular}

\section{INTRODUCTION}

Earnings typically refer to after-tax net income. Ultimately, a business's earnings are the main determinant of its share price, because earnings and the circumstances relating to them can indicate whether the business will be profitable and successful in the long run. Earnings are perhaps the single most studied number in a company's financial statements because they show a company's profitability. An earnings announcement is typically made on a specific date during earnings season and is preceded by earnings estimates issued by equity analysts. When the company has been profitable leading up to the announcement, their share price will usually increase after the information is released. Because the earnings announcement is the official statement of a company's profitability, the days leading up to the announcement are often filled with speculation. The current study deals with an analysis of impact of quarterly earnings announcement on the stocks which are traded in capital market. The entire study is based on secondary data extracted from various sources like, books, journals, websites etc. The sample is selected from NSE listed top 30 companies on $11 / 06 / 2014$. The main objective of the study is to have a look upon the impact of earnings announcement on performance of the respective stock in the stock market.

\section{OBJECTIVES}

The core objective of this study is to identify the reaction of stock market on corporate quarterly earnings announcement. However in order to achieve the main objective, the following specific objectives have been framed:

- To compare the performance of various stocks before and after earning announcement.

- To compare the impact of Earnings Announcement among various stocks under study

- To offer meaningful suggestions to the investors based on the study.

\section{METHODOLOGY:}

The study is purely based on secondary data collected from books and internet 
sources. The sample size of the study is 30 companies and the sample is selected from top (based on market capitalization) 30 NSE listed companies. Daily closing prices and annual earnings announcement dates were obtained for a sample of firms listed on the NSE. We use daily data and set the event window at fifteen (15) days before and fifteen (15) days after the earnings announcement day. The announcement day is represented by day zero (0).

$-15,-14,-13,-12,-11 \ldots-2,-1,0,+1,+2 \ldots$ $+12,+13,+14,+15$.

\section{TECHNIQUES OF ANALYSIS:}

Daily returns for each sample company has been computed for the estimation period and also for the event period as

$\mathbf{R}_{\mathbf{i t}}=\frac{\mathbf{P}_{\mathbf{i t}}-\mathbf{P}_{\mathbf{i}(\mathrm{t}-1)}}{\mathbf{P}_{\mathbf{i}}(\mathrm{t}-1)}$

Where, $\mathrm{Ri}=$ Actual daily stock return, $\mathrm{P}_{\mathrm{it}}=$ closing price of security ' $i$ ' on day $t$ and $\mathrm{P}_{\mathrm{i}(\mathrm{t}-1)}=$ closing price of stock on day $(\mathrm{t}-1$

Average Return (AR's) for each relative day is calculated by

$\mathbf{A R}_{\mathbf{t}}=\sum_{\mathbf{t}=\mathbf{1}}^{\mathbf{n} \sum} \frac{\mathbf{R}_{\mathrm{it}}}{\mathbf{N}}$

Where, $\mathrm{i}=$ the number of securities in the study

$\mathrm{N}=$ Total number of securities

$\mathrm{t}=$ the days surrounding the event study.

\section{ANALYSIS}

Table No.1: Return and Correlation of NSE 30 Companies for the Quarter 1

\begin{tabular}{|c|c|c|c|c|c|}
\hline \multirow[b]{2}{*}{$\begin{array}{l}\text { Sl. } \\
\text { No }\end{array}$} & \multirow[b]{2}{*}{ Company } & \multicolumn{4}{|c|}{ Quarter First } \\
\hline & & $\begin{array}{c}\text { Pre } \\
\text { Announcement }\end{array}$ & $\begin{array}{l}\text { On the Date of } \\
\text { Announcement }\end{array}$ & $\begin{array}{c}\text { Post } \\
\text { Announcement }\end{array}$ & Correlation \\
\hline 1 & $\mathrm{ACC}$ & -0.028005 & -0.212653 & 0.122919 & -0.0778 \\
\hline 2 & Ambuja Cem & 0.571557 & 1.177415 & 0.311742 & -0.3568 \\
\hline 3 & Asianpaint & 0.168485 & 1.639167 & 0.479575 & 0.0839 \\
\hline 4 & Axis Bank & -0.134981 & 1.780863 & -0.741884 & 0.1933 \\
\hline 5 & Bajaj-Auto & 0.630210 & -0.054575 & 0.222515 & 0.3501 \\
\hline 6 & Bank Of Baroda & -0.870998 & 2.917356 & 0.032854 & -0.2167 \\
\hline 7 & Bharti Airtel & 0.242529 & 1.508141 & 0.865295 & -0.2251 \\
\hline 8 & BHEL & -0.359150 & 2.869440 & -0.639117 & -0.3081 \\
\hline 9 & BPCL & 0.041772 & 2.016624 & -0.495964 & -0.2366 \\
\hline 10 & Cairn & 0.030032 & 1.241379 & 0.307337 & 0.4364 \\
\hline 11 & Cipla & 0.335382 & 1.479781 & 0.231354 & -0.2139 \\
\hline 12 & Coal India & -0.380363 & 0.809784 & -0.094624 & -0.0320 \\
\hline 13 & DLF & -0.503000 & 4.331034 & -0.669826 & 0.5697 \\
\hline 14 & GAIL & 0.242977 & 3.702522 & 0.115885 & 0.0544 \\
\hline 15 & Grasim & 0.143665 & -0.952297 & 0.012974 & 0.3334 \\
\hline
\end{tabular}




\begin{tabular}{|r|l|r|r|r|r|}
16 & HCL Tech & 0.224067 & -2.268041 & 1.088022 & 0.2512 \\
\hline 17 & HDFC & 0.240438 & 1.205847 & -0.437514 & 0.1798 \\
\hline 18 & HDFC Bank & -0.049960 & -0.112024 & 0.148784 & -0.1715 \\
\hline 19 & Hero Moto Corp & 0.101873 & 2.137639 & 0.358987 & 0.4192 \\
\hline 20 & Hindalco & 0.020733 & 2.104208 & 0.181192 & 0.1440 \\
\hline 21 & Hindustan Unilvr & -0.090617 & 0.384517 & 1.179761 & 0.2750 \\
\hline 22 & ICICI Bank & -0.286294 & -0.266169 & -0.590890 & 0.0142 \\
\hline 23 & IDFC & -0.824040 & 1.092470 & -0.205252 & -0.0962 \\
\hline 24 & Indusind Bank & -0.372364 & 0.962670 & -0.136209 & 0.2148 \\
\hline 25 & Infosys & 0.048732 & -1.914881 & 1.113627 & -0.4561 \\
\hline 26 & ITC & -0.265728 & 0.493294 & 0.834508 & 0.0028 \\
\hline 27 & Jindal Steel & -1.281942 & 2.851230 & -0.349403 & -0.1649 \\
\hline 28 & Kotak Bank & -0.273477 & 0.242315 & -0.191875 & 0.2595 \\
\hline 29 & L\&T & 0.035358 & 3.107465 & -2.712485 & -0.1371 \\
\hline 30 & Lupin & 0.199646 & -0.550259 & 0.922697 & -0.0227 \\
\hline Average Return & $\mathbf{- 0 . 0 8 1 4 4 9}$ & $\mathbf{1 . 1 2 4 1 4 2}$ & $\mathbf{0 . 0 4 2 1 6 6}$ & \\
\hline
\end{tabular}

\section{Source: Authors Compilation}

As per the Table No.1; in the quarter first,

Baja Auto has highest return in the period of pre-announcement days but in the post announcement days Hindustan Uniliver yield highest return. In the preannouncement days: Ambuja cement, Asian Paint, Baja Auto, Bharti Airtel, BPCL, CAIRN, Cipla, GAIL, Grasim, HCL, HDFC, Hero motor, Hindalco, Infosys, L\&T and Lupin stocks have positive returns and in post-announcement days; ACC, Ambuja cement, Asian paint, Bank of Baroda, Bharti Airtel, CAIRN, Cipla, GAIL, Grasim, HCL Tech, HDFC, Hero motor, Hindalco, Hindustan, Infosys, ITC and Lupin have positive returns.

In the pre-announcement days Jindal steel has highest negative return but in post announcement days L\&T has highest negative return. In the pre-announcement days; ACC, Axis Bank, Bank of Baroda, BHEL, Coal India, DLF, HDFC, Hindustan Unilever, ICICI Bank, IDFC, Indusind Bank, ITC, Jindal steel and Kotak Mahindra Bank have negative return. But in the post announcement days; Axis Bank, BHEL, BPCL, Coal India, HDFC, ICICI Bank, IDFC, Indusindia Bank, Jindal steel, Kotak Bank and L\&T have negative return.

In the first quarter; Asian Paint, Axis Bank, Baja Auto, Cairn, DLF, Grasim, GAIL, HCL Tech, HDFC, Hero Moto, Hindalco, HUL, ICIC Bank, Indusind Bank and Kotak Bank shown positive correlation between the returns of pre and post earnings announcement returns. Whereas ACC, Ambuja Cem, Bank Of Baroda, Bharti Airtel, Bhe, BPCL, Cipla, Coal India, HDFC Bank, IDFC, Infosys, 
Jindal Steel, L\&T \& Lupin shown negative correlations. A return on the date of earnings announcement is higher than returns before and after the earnings announcement.

As per the Table No 2: In the second quarter, BPCL has the highest return in the pre-announcement days but in the post announcement days, Axis bank has the highest returns. In the pre-announcement days; ACC, Bajaj Auto, Bank of Baroda, BPCL, Coal India, Gail, Grasim, HCL Tech, Hindalco, ITC and Lupin have positive return. Whereas in post announcement days; Ambuja Cem, Asianpaint, Axis Bank, Bajaj Auto, Bank Of Baroda, Bharti Airtel, Bhel, Cairn, Dlf, Gail, Grasim, HDFC, HDFC Bank, Hero Moto Corp, ICICI Bank, IDFC Indusind Bank, Infosys, ITC, Jindal Steel, Kotak Bank, L\&T And Lupin have positive return.

When we look at the pre-announcement days; Ambuja Cem, Asianpaint, Axis Bank, Bharti Airtel, Bhel, Cairn, Cipla,
DLF, HDFC, HDFC Bank, Hero Moto Corp, Hindustan Unilvr, Icici Bank, IDFC, Indusind Bank, Infosys, Jindal Steel, Kotak, Bank and L\&T have the negative return. But in the post announcement day following stocks are having negative return; Asianpaint, Axis Bank, Bajaj Auto Bharti Airtel, Bhel, BPCL, HCL Tech and Hindustan Unilvr.

In The Second Quarter; ACC, Ambuja Cem, Bank Of Baroda, Cairn, Cipla, Coal India, DLF, Grasim, HDFC, HDFC Bank, Hero Moto Corp, ICICI Bank, Indusind Bank, Kotak Bank And L\&T Stocks showing Positive Correlation and remaining stocks showing negative correlation. Most of the stocks are showing negative correlation between returns before the earnings announcement and after the earnings announcement. When we compare the average returns of all industries taken together of pre, post and on date of announcement, returns on the date earnings announcement is higher than other two returns.

Table No.2: Return and Correlation of NSE 30 Companies for the Quarter 2

\begin{tabular}{|r|l|r|r|r|r|}
\hline \multirow{2}{*}{$\begin{array}{c}\text { Serial } \\
\text { No }\end{array}$} & \multicolumn{1}{|c|}{ Company } & Announcement & $\begin{array}{c}\text { Quarter Second } \\
\text { On the Date of } \\
\text { Announcement }\end{array}$ & $\begin{array}{c}\text { Post } \\
\text { Announcement }\end{array}$ & Correlation \\
\hline 1 & ACC & 0.612408784 & -1.1286 & 0.3371 & 0.1402 \\
\hline 2 & Ambuja Cem & -0.12319044 & -1.3969 & 0.5220 & 0.3244 \\
\hline 3 & Asianpaint & -0.13065009 & 0.3445 & 0.9731 & -0.6398 \\
\hline 4 & Axis Bank & -1.801046353 & 3.7637 & 1.3613 & -0.0799 \\
\hline 5 & Bajaj-Auto & 0.033191119 & 1.6378 & 0.2140 & -0.0286 \\
\hline 6 & Bank Of Baroda & 0.26254581 & 0.9827 & 1.2487 & 0.2670 \\
\hline
\end{tabular}




\begin{tabular}{|r|l|r|r|r|r|}
7 & Bharti Airtel & -0.402938735 & 1.2396 & 0.5474 & -0.2983 \\
\hline 8 & BHEL & -0.180669693 & 2.7293 & -0.0359 & -0.3394 \\
\hline 9 & BPCL & 0.803563684 & -1.4792 & 0.6161 & -0.3451 \\
\hline 10 & Cairn & -0.203565618 & -0.3450 & 0.1527 & 0.3598 \\
\hline 11 & Cipla & -0.129054946 & -0.1387 & -0.1762 & 0.0090 \\
\hline 12 & Coal India & 0.174715573 & 1.0358 & -0.4016 & 0.3951 \\
\hline 13 & DLF & -0.666518666 & 6.9114 & 1.0458 & 0.0446 \\
\hline 14 & GAIL & 0.594811367 & -0.9152 & 0.5482 & -0.5636 \\
\hline 15 & Grasim & 0.432559027 & -0.7105 & 0.1916 & 0.4625 \\
\hline 16 & HCL Tech & 0.191361345 & -1.4809 & -0.0665 & -0.3054 \\
\hline 17 & HDFC & -0.385103682 & 2.8328 & 0.2257 & 0.0883 \\
\hline 18 & HDFC Bank & -0.494572895 & 3.1363 & 0.6195 & 0.4973 \\
\hline 19 & Hero Moto Corp & -0.203791346 & -0.5052 & 0.2795 & 0.3075 \\
\hline 20 & Hindalco & 0.145252407 & -1.2511 & 0.2689 & -0.2490 \\
\hline 21 & Hindustan Unilvr & -0.265937999 & -1.3148 & -0.1019 & -0.7106 \\
\hline 22 & ICICI Bank & -0.61789372 & 3.0668 & 0.7857 & 0.3542 \\
\hline 23 & IDFC & -0.284090091 & 3.1800 & 0.9941 & -0.1219 \\
\hline 24 & Indusind Bank & -0.691614697 & 3.8780 & 0.7680 & 0.5181 \\
\hline 25 & Infosys & -0.334267061 & 0.0664 & 0.6337 & -0.1838 \\
\hline 26 & ITC & 0.10802637 & 0.7638 & 0.0043 & -0.3458 \\
\hline 27 & Jindal Steel & -0.024350592 & -1.2739 & 0.2697 & -0.1115 \\
\hline 28 & Kotak Bank & -0.274155055 & 1.0323 & 0.2265 & 0.0555 \\
\hline 29 & L\&T & -0.126562656 & 1.4263 & 1.2948 & 0.3097 \\
\hline 30 & Lupin & 0.189974749 & -0.5024 & 0.4211 & -0.0804 \\
\hline Average Return & $\mathbf{- 0 . 1 2 6 3 8 5 4 7}$ & $\mathbf{0 . 8 5 2 8 3 2 7 9 7}$ & $\mathbf{0 . 4 5 8 9 1 6 1 7}$ & \\
\hline
\end{tabular}

\section{Source: Authors Compilation}

\section{FINDINGS AND SUGGESTIONS}

It is true that share market is the most sensitive parameter of the economy. It responds immediately, even to the negligible changes. It is obvious that the earnings, economic policy-making decision shall have significant impact on the sensitive parameter, stock market. This study examines the impact of earnings announcements on stock market. In the most of the quarters the actual returns is highest on the date of earnings announcement than pre and post earnings announcement date. Investors are not sure about the industry or the companies that are going to be benefitted from the coming earnings, they would be less interested to buy the shares during the pre-earnings period and similarly, the investors who have already invested in those companies which are going to be punished by the earnings will dispose all their holdings before the earnings. This leads to more pressure on sale of shares than purchase of shares during pre-earnings period. After 
the earnings, the trend would be different.

The investors are getting information about the industries which are benefitted from the earnings and they start investing in the companies of such industries and it makes the market to move upward direction during the post-earnings period. Since the post-earnings risk is less and return is high, the study concludes that post-earnings period best investment.

\section{BIBLIOGRAPHY:}

[1] Balla V. K. (2002), Portfolio Analysis and Management, Sulthan Chand and Co. Ltd., New Delhi.

[2] BhatSudhindra (2008), Security Analysis and Portfolio Management, Excel Books, New Delhi.

[3] Booie.Zvi, Kane Alex and et.al.(2006), Investments, $6^{\text {th }}$ edition, Tata McGraw Hill, New Delhi.

[4] Chandra Prasanna (2008), Investment Analysis and Portfolio Management, $3^{\text {rd }}$ edition, Tata McGraw Hill, New Dehi.

[5] Fisher. E. Donald and Jordan. J. Ronald (2006), Security Analysis and Portfolio Management, Pearson Prentice Hall.

[6] Kevin. S (2008), Portfolio Management, $2^{\text {rd }}$ edition, PHI Learning Pvt. Ltd, New Delhi.

[7] PandianPunithavathy (2004), Security Analysis and Portfolio Management, Vikas Publishing House Pvt. Ltd, New Delhi.

[8] Reilly. K. Frank and Brown. C. Keith (2006), Investment Analysis and Portfolio Management, $8^{\text {rd }}$ edition, Cengage Learning India Pvt. Ltd, New Delhi.

[9] www.bse.com

[10] www.rbibulletin.com 